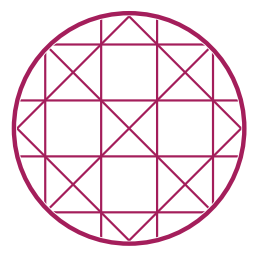

Cabecinhas, R. \& Abadia, L. (eds.) (2013)

Narratives and social memory: theoretical and methodological approaches

Braga: University of Minho

SBN: 978-989-8600-04-2

pp. $327-343$

\title{
Adozinda Goes to the Feminine Reading Room: a Segregated Space for Women in a Portuguese Public Library under a Fascist State
}

\author{
Paula Sequeiros \& Sónia Passos \\ ${ }^{1}$ University of Coimbra \& University of Porto, Portugal \\ ${ }^{2}$ Independent researcher \\ paulasequeiros@ces.uc.pt \\ soniacpassos@gmail.com
}

\begin{abstract}
The public event of the inauguration of a Feminine Reading Room in the Municipal Public Library of Porto, held on the 24th November 1945, sets the motto for the construction of a historically and sociologically based analysis of the modes of usage of public and semipublic space - namely libraries - used by women and their meanings in those days.

Within the framework of a qualitative approach, sources such as literature, photography and personal interviews are added to documentary data from institutional archives. A fictional narrative, built from historical data, is inserted to sustain our analysis, where Adozinda is the character embodying a woman reader who crosses the city to visit the recently inaugurated Feminine Reading Room. Two female figures punctuate this narrative, Virgínia de Castro e Almeida, the person after whom this room was named, and Tília Dulce Machado Martins, the main legator of the collection it holds. Using this fictional narrative, we aimed at reconstructing a holistic context for the facts as they might have happened through a pleasurable reading of a plausible text. These women's diverse histories are also inserted in that context.

Fiction is a resource used to inscribe data on the social, economic, and political situation in the city and in the country at that time, with an emphasis on women and their uses of public space.

As to the theoretical framing of public and semi-public use of the space, the theory of gendered spaces, as opposed to separate spheres, is evoked and confirmed to account for the presence of women in public space, according to gender and social class roles, a presence which is however socially invisibilised.

We conclude that the Room's space, initially segregated for moral reasons, was later transformed through an appropriation which went from separatism to integration, as a response to ethical claims gaining ground in society. This separatism was, therefore, an intermediate step towards a more equalitarian use of space.
\end{abstract}

Keywords

Public libraries; public space; women; gendered space; Portugal

\section{WhAT YOU ARE ABOUT TO HEAR}

A librarian once told us a story about a special reading room, for women only, which had existed in the Municipal Public Library of Porto. Later on, a magazine article reporting on 
the inauguration of that room was eventually located by one of the authors. The singularity and significance of this Feminine Reading Room, a hardly known fact, lead us to research it further. Leaning on that text, we moved to other primary sources: the library's administrative archives and the municipality's historical archives, some photographs retrieved at the Centro Português de Fotografia (CPF, Portuguese Centre for Photography). Drawing from both historical and sociological theory and literary texts, a qualitative approach was designed.

The aim was not solely to reconstruct the existence of such a specialised room but to understand its social significance within the context of the use of public space by women in those times and for that urban location. In pursuing this aim we concretised some points of the feminist research agenda, revealing women's loci and perspectives and, while doing it, contributing to the production of a more comprehensive knowledge of society, through our commitment to a research path that may support the critique of gender inequalities (Devault, 1996).

Two female figures emerged during our research, Virgínia de Castro e Almeida (18741945) and Tília Dulce Machado Martins (c. 1890-1937).

The Feminine Reading Room was named Virgínia de Castro e Almeida. Having died in Lisbon some months before its inauguration ${ }^{1}$, she was evoked, in the opening ceremony speech, as a renowned novelist and a children's books writer ${ }^{2}$, not a "revolutionary", but a woman "leaning towards a calm beauty"; not an advocate of the current feminism, but of a woman who is "an educated, balanced woman's voice, pure, who aspires to a place by her male companion, to share his grieves, his works, his joys" (Inauguração... 1945, p. 427). Virgínia had also played a salient role in the history of Portuguese filmmaking. She lived in France and Switzerland for some years, and started a producing business, Fortuna Films, registered in Lisbon and Paris (Baptista, 2003). In 1929 she was one of the counsellors with the Portuguese Popular University, a progressive, anti-fascist institution (Associação..., 2001). In later years, Virgínia had, however, adhered to the regime's fascist ideology, producing a series of children's books devoted to the glorification of Portuguese nationalistic myths, ideological instruments conveying "the principle of authority and the virtue of abeyance" (Balça, 2007). And this was surely the reason for such a public demonstration of appreciation from the local authorities.

Members of the library staff pointed us in the direction of Tília Dulce Machado Martins $^{3}$, the person who legated most of the books to be incorporated in the reading room. Born in Brazil, from a family of broad-minded republicans, her late husband had been a minister of the first Republic and a colonial governor of India ${ }^{4}$. In her will, dated from 1937, she donated 2992 books which would later on be incorporated in the reading

\footnotetext{
$\overline{1}$ see Virgínia Folque de Castro e Almeida Pimentel Sequeira e Abreu, in Fundação... 2000.

2 according to França (1983), the ABC magazine published a list of the twelve most popular Portuguese authors in 1928 which included Virgínia de Castro e Almeida.

${ }^{3}$ see Tília Dulce Machado Cardoso in GeneAll.net - Portugal; she became Tília Dulce Machado Nogueira, following her first marriage; she took her third husband's surname, Martins, later.

${ }^{4}$ her third husband, here referred to, was Mariano Martins; some of the books from this legacy are signed by their previous owner, Henrique José Santos Cardoso Júnior, her second husband, a chemist and a journalist, one of the founders of the Republican Party in Porto (family ties reported by relatives).
} 
room's collection (BPMP,1984). Her name also shows up as a donator to a national museum in Lisbon (Pinto, 1939). Several of these books had belonged to more than one owner, as documented by their personal signatures, or to a privately owned Reading Club ${ }^{5}$. Some were probably bought second-hand, according to bookshop stamps and former owners' signatures, and others might have been inherited ${ }^{6}$. This was, undoubtedly, a bibliophile's collection and one characterised by progressive ideas. As Virgínia was the daughter of the 1st Count of Nova Goa (India), her acquaintance with Tília Dulce was very likely, and an interviewee came to confirm that they were friends. However, we could not confirm whether this donation was purposefully made for the new Feminine Reading Room.

We crossed several types of data: Virgínia's writings and biographical data, biographical data provided by the family of Tília Dulce, data on the library's history from the archives and from one publication of the municipality of Porto, the reading room's bibliographical catalogue, photos relating to both women and to the city of Porto, register offices documents of Portugal and Brazil, interviews and conversations with senior librarians, and personal memories of childhood. Using a chain of contacts, we were lucky enough to locate and interview one woman who had visited the Feminine Reading Room in her youth and converse with another one, her contemporary. Both provided information on cultural and leisure habits of Porto's young women in those days.

A fictionalised narrative emerged to embody and reassemble those historical fragments, voiced by an imaginary female character. We created this character and the story based upon what a daily routine of a middle-class young woman in the city of Porto in the 1940's might have been. For a denser context, additional data are provided along with the narrative, as a scenario in the background of such a reconstructed portrait. This data consists of the sources of the 'real' history such as literature, photography and personal interviews are added to documentary data from institutional archives.

Furthermore, we must also be aware of the political and social situation in those days in Portugal and how it reflected in the daily life of readers and in a library's activities. The German Army's surrender had been announced on May 8th 1945. Public demonstrations followed the allies' victory, in the hope of Salazar's overthrow. "Free elections" were announced for October as an effort from the fascist dictator to legitimise his position visà-vis the foreign victorious powers. After the elections, repression increased, and a librarian is - again - suspended from his duties on charges of political activities against the government, together with several other civil servants all over the country'. Print materials where subject to censorship. Dictatorship takes regressive measures, such as putting an end to the co-education initiated by the republicans, progressively cutting compulsory education time, establishing four years for boys and three years for girls from 1936 to 1960, and lowering the level of learning contents. Unique, official manuals are enforced, repeatedly

\footnotetext{
5 "O Jardim do Povo - Gabinete de Leitura Portugueza e Franceza" [The People's Garden - Portuguese and French Reading Cabinet], founded in 1882.

6 some books are signed by a previous owner Henrique José Santos Cardoso Júnior, and their edition dated the end of the 19th century; we were told by relatives that he was Tília Dulce's second husband, a chemist and a journalist, a founder of the Republican Party in Porto.

7 Narciso de Silva José de Azevedo will be arrested in 1948, as he had been in 1939 (administrative files, letter ref. 139/48).
} 
depicting the woman as a housekeeper (Neves \& Calado, 2001). Instruction for the most able, work for all, Salazar's slogan proclaimed. Less educated than teachers, teaching instructors - regentes - were assigned to many primary schools, earning $250 \$$ Escudos for these coveted, although underpaid positions, in 1945 (Guimarães, 2004). In 1946, regular primary teachers earned $750 \$$, grammar school teachers $2400 \$$, clerks $2400 \$$; a family with three children would spend a very strict minimum of $3690 \$$ in housing and food, health expenses excluded; from 1939 to 1946, prices rose by $148 \%$ and so real wages fell sharply (Rosas, 1990). Modas e Bordados (Fashion and Embroideries) a very popular monthly magazine, cost $7 \$ 50$ (Guimarães, 2004).

\section{Here, the Tale of a Female Reader Begins}

Adozinda lives near the public library. Berta, her schoolmate, told her about this new room, just for women. Berta's mother, being a renowned writer, had attended the inaugural ceremony. Adozinda kept the magazine's clipping reporting the event ${ }^{8}$. One picture shows several people gathered for the inauguration of the Feminine Reading Room in Porto's Municipal Public Library, last November: the mayor, several councillors, the library's director, some of the city's intellectuals and several women. The director praised the role of the Arts in "dignifying and elevating" spiritual life. Addressing the mayor, he proclaimed that if some "limpid, angelical figures" might be seen reading behind those doors, in the future, even if only to read The imitation of Christ, the mayor may be assured to have accomplished the best compensation for his administrative life.

Going to the Faculty of Pharmacy occupies most of Adozinda's time now. She was considering Medicine, but papa dissuaded her: that was a tough course and Pharmacy is such a nice graduation for a girl, most of her schoolmates are girls?.

She usually goes out with relatives or other female friends. She often accompanies her mama, who enjoys having tea with her friends downtown in that exquisite tearoom. Every now and then Adozinda goes to cinema matinées with Berta. Thursdays attendances are especially suitable for young ladies. When she gets bored, window-shopping is always welcome, she may even look for some novelties in the silk merchants or for some elegant magazine. Mama is always knitting or embroidering something new for her trousseau, whenever she's free from her charity duties with the poor and the sick.

She only has to avoid some streets, sidewalks of cafés or pubs where men are known to gather to make flirtatious remarks at passing girls. Now in her twenties, she knows that she must keep her eyes down when crossing with men in the streets. Otherwise she risks being mistaken for the wrong kind of girl, and that kind of girls and women do show up, leaning against the open doors of boarding houses and pubs so common in a nearby street.

Today there are some children playing in São Lázaro's park, across the street, watched over by their families' maids. Young soldiers, away from home, frequent it too, hoping to get on speaking terms with those young maids.

\footnotetext{
8 (Inauguração..., 1945).

9 (Lamas, 1950).
} 


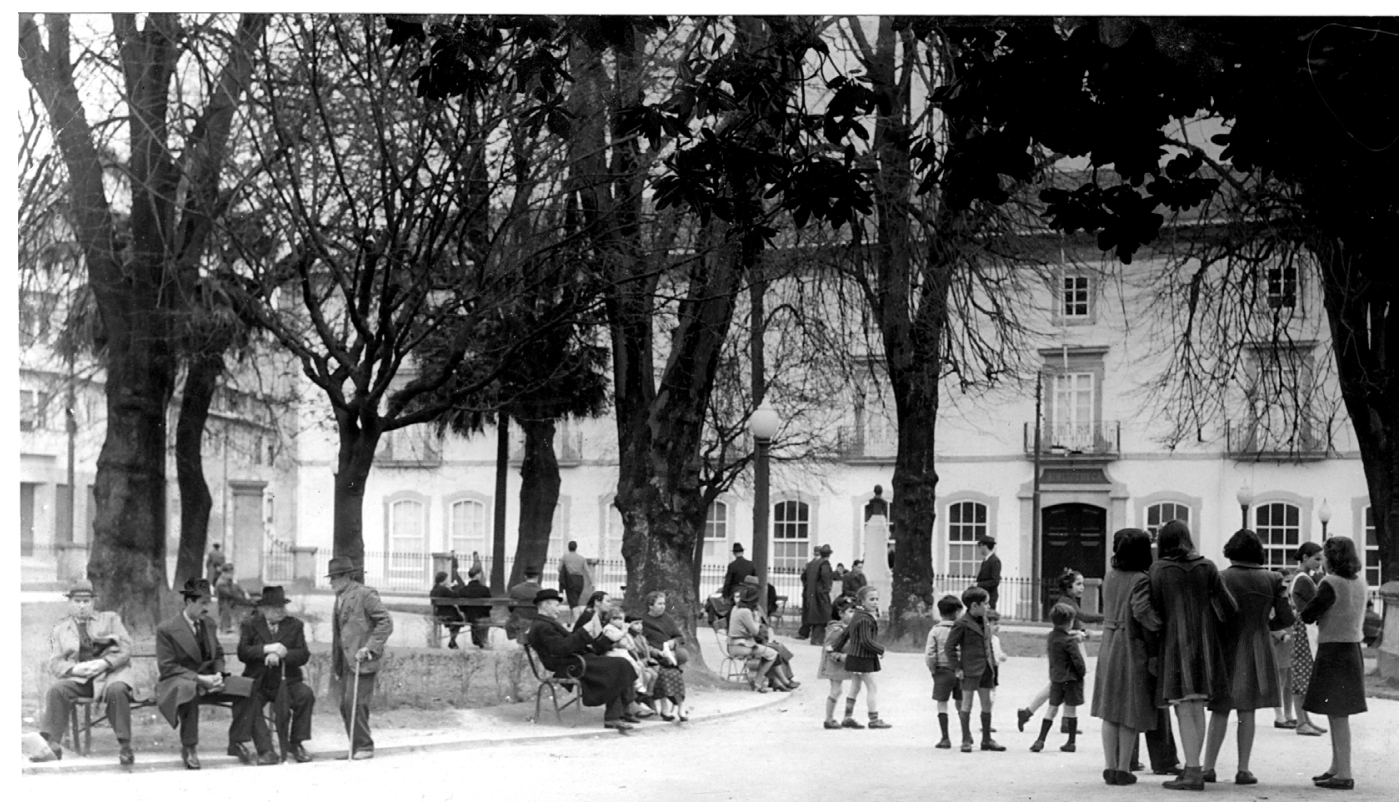

Figure 1: São Lázaro's park, 1950. Some women are sitting on the benches; behind the children in the foreground, a maid in white apron - former O Primeiro de Janeiro newspaper's photographic archive.

It's early, in a winter morning, fishwives are coming up from the river pier, balancing baskets upon their heads and shouting out the virtues of their fresh produce. Other women come to the city to sell vegetables, brought by wagons coming from the near farms of Campanhã ${ }^{10}$. She no longer crosses the women bread sellers and milkmaids delivering fresh rolls and milk to their regular costumers. That part of the city's daily routine is staged still at dusk, some time before her breakfast is served to her in bed by Maria, the servant-maid. She left her small village in Minho to escape famine at the age of fourteen. After her father died in World War I, her mother was no longer able to raise so many children. She must get accustomed to earning her living, she does not expect to be a housewife upon marrying ${ }^{11 .}$

At her mama's request, Adozinda began teaching Maria to read. Although she went to school she was not able to read those romantic photo novels she so appreciates ${ }^{12}$.

Adozinda arrives at the library and finds her way into the Feminine Reading Room. This has been conveniently placed by the front entrance, on the ground-floor besides the cloister garden, and so she does not have to cross men in the staircases leading to the other rooms.

\footnotetext{
10 Lamas (1950) for this and other aspects of working women lives; for the daily life in the parish of Campanhã see life narratives by Pombo (2005).

11 "Housewives are practically non-existent among the popular classes. They all work, more or less, outside the home. If not industrial workers, they are rural labourers, peddlers, servants, and maids. Even when not working to a fixed timetable, they don't stay at home much, not more than the time needed for domestic tasks, for earning a living is enforced on them, even if this means occasional services." Rich women dedicate themselves to charity. "Some young female aristocrats also engage in learning "only to have some general notions of culture, not meaning by that to be in accordance with the professional training of a woman." (Lamas, 1950, p. 460).

12 "A book or a newspaper never reaches their modest houses, nor is there a library in the hamlet, however modest, where to practise the little they have learned." (Ferreira, 1935, p. 11-18). The author provides a very vivid description of the living conditions of working women in the pages of Vida Feminina [Feminine Life].
} 
Virgínia de Castro e Almeida has her name inscribed in a plaque at the entrance of the new Room. Adozinda knew Virgínia as the author of several articles in the feminine supplement to the newspaper her father usually buys ${ }^{13}$. She felt curious and excited as this was a new opportunity to leave home and maybe find some of her acquaintances.

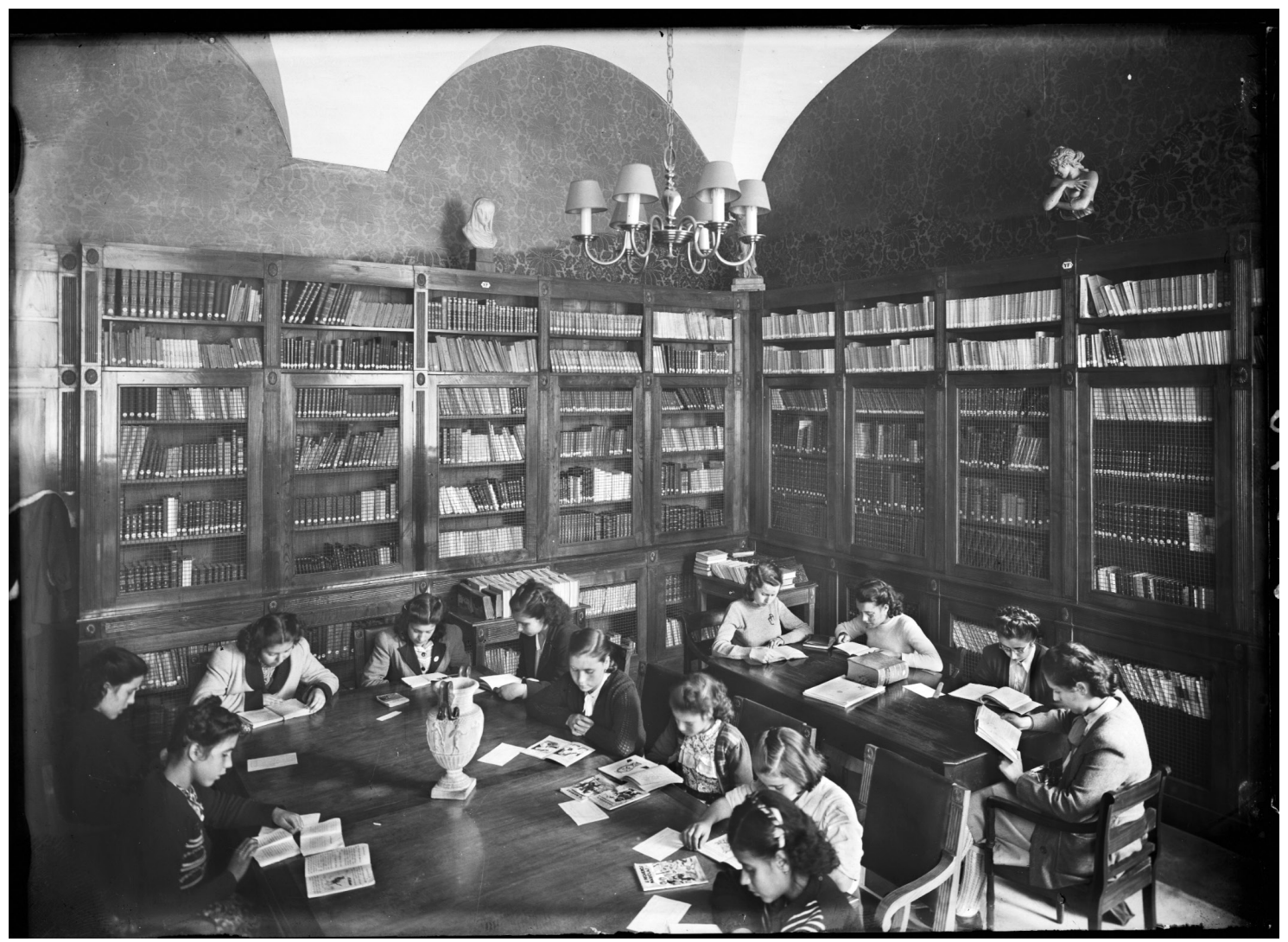

Figure 2: The Feminine Reading Room, undated, Alvão studio, ref. ALV004609, CPF/DGARO/MC.

She wonders which book to pick and glances around. English style furniture, a round table with a Wedgwood-like Greek vase, a chandelier, ceramic busts decorating the bookshelves, wallpaper, a carpet and curtains, all offer a distinguished touch to this small room ${ }^{14}$. Special care has been paid to this room, an assistant explains, the General Reading Room has no such luxuries! As a matter of fact it is the only room equipped with a heater. Now that war is over, restrictions over power consumption seem to be alleviated ${ }^{15}$. She feels soothed by this comfort. Berta's home is always so cold.

Then Berta shows up, they don't have classes that day. Berta's parents both work -, her mother earns her living as a primary-school teacher - they consider themselves neither poor

\footnotetext{
$\overline{13}$ the supplement Vida Feminina (Feminine Life) was distributed with O Século (The Century) during the fifties (Guimarães, 2004).

${ }^{14}$ similar care and type of decoration for feminine parlours is referred by van Slyck, 1996; on how décor may support the gendering of space, see Hoberman (2002) and Merrett (2010).

15 During World War II, there were food shortages and rationing. Unemployment and wage cuts, for a reduced working time, were frequent. An increase in the number of beggars and prostitutes in the city, as well as a rise in food thefts and assaults on bread distributors preoccupied the police. In 1944, several hunger marches occurred in the city and the vicinities. High prices in house rental lead to industrial workers and impoverished families to gather in shacks. Most homes did not have water supply or sewage. Epidemics were frequent and lethal, and tuberculosis was a major threat (Rosas, 1990). Several library workers were stroke by the disease and sanitary inspections were frequent among them according to BPMP official correspondence 1937/1938.
} 
nor rich. Her mother works hard, teaching two, three or even four grades during a single year. Berta only occasionally goes to the cinema with her brother, “life being so hard!". Every fortnight or so she goes to the café and meets her friends, she sometimes even ventures to enter unchaperoned, being a girl with an "advanced mentality" 16.

As Berta can easily catch the tramway to the library, she no longer has to buy so many books for her study. This time she requests a Latin Dictionary to prepare for Easter-term exams. Most of the girls she joins in the Feminine Reading Room came in to study.

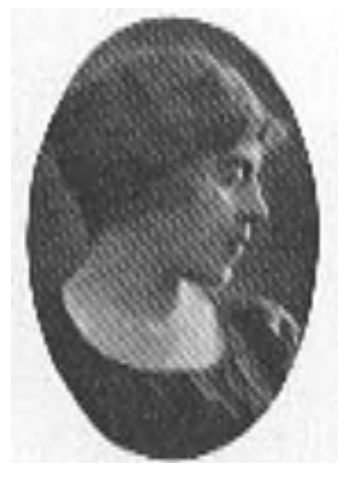

Figure 3: Virgínia de Castro e Almeida, photo published in Illustração Portugueza, nr. 11, Nov. 1911

Berta remembers she had read some books by Virgínia de Castro e Almeida as a child, and whispers into Adozinda's ear. She then asks the assistant which books by Virgínia are available. Adozinda peeps into the cabinet and chooses $A$ mulher [The woman]. It is a small book she quickly reads. The author's accounts of women's education in Switzerland stirs her imagination. Most of all, she is surprised by her statement:

In feminism, as in socialism, as in all grand beliefs and in all hopes that have ennobled the human spirit, and have taken it to the conquest of a redemptive ideal, there are the exalted, the fanatic, the non-understanding, the ones who go beyond the dream, the ones who do not measure the part that one must leave for time and who think they're able to realise, in a lifetime space, what the work of the centuries alone will one day do.

So Virgínia had been a feminist? She would never have thought of it! And the text goes on: "Women of my country!... Cinderellas with an empty brain...; luxury dolls, dressed up like the "ladies in Paris'..."

These ideas make her a bit uncomfortable. Well, times have changed. She checks the date out, to discover that the book had been written soon after her mother was born.

The cautionary words on Virgínia, used in the inauguration speech, had intrigued her. But now she realizes that they contradict Virgínia's own words, in earlier days. So she had been a feminist, only regretting to have mistaken feminism for a "grotesque and vague, maybe dangerous, utopia." But then "'a great master, Life, harsh and prodigious [...] whose teachings never fail" taught her better, only to recognise that feminism was "a grand and generous idea of redemption, gravely advancing with the majestic serenity of all invincible forces destined to change the face of the world" (Almeida, 1913, p.14).

\footnotetext{
${ }^{16}$ based on the interview with Fernanda, the former user of the Feminine Reading Room.
} 
Thus Virginia's passionate exhortation, published in 1913 shortly after the republican revolution of 1910:

\begin{abstract}
Women of my country!... Cinderellas with an empty brain, who wait, sitting by the fire-place and with morbid tremors, for the hypothetical appearance of prince charming, grave maid-servants, who spend their lives with the pantry keys and a needle in hand, without the slightest idea of domestic economy or hygiene, confusing honesty with the neglect of beauty; beasts of burden or reproduction, surrounded by children who they know not how to raise or educate; luxury dolls, dressed up like the ladies in Paris and all their intelligence absorbed in decoding fashions, incapable of any other interest or any other comprehension; [...] passive instruments in the skilful hands of Jesuitism which moulds them like wax; fervent servants of snobbery and gossipping; superficial imitators of models they barely know... Poor women of my country! ${ }^{17}$
\end{abstract}

She is only surprised that books such as A mulher are kept in the library at all. Still, she deeply empathises with the young Virgínia's confidences.

Those [young girls'] reunions and other similar entertainments always left an unpleasant feeling, got on my nerves, ended up distressing me, persuading me even more of my manifest inferiority. [...]

I enjoyed the soirées or dinners involving serious people much more, where my individuality disappeared, where no one noticed me, where I could indulge in my observations all by myself, digesting what others said in silence, not having to pretend, with no one cueing me to enter the scene, to perform a role. [...] and, as they were social, political, literary or critical matters, in general, inaccessible to commentaries and even to the understanding of a girl of my age, who was advised, most of all, to walk down the stairs like a little bird, not to be embarrassed to speak in French before others, not to act shy or be a lone wolf, to consider dressing up more, I got used to discuss with myself all the ideas debated before me but which I was not allowed to talk about, so came to organise my brain in a very curious mode. ${ }^{18}$

Observing Adozinda's uneasiness, Berta takes a glimpse into A mulher as well. Murmuring, they exchange a few ideas. Then Berta comments that she is not surprised at all, her mother had known Tília Dulce. She had been a cultivated, rich woman who donated most of the books they now see in that room behind the bookcases' glass doors. They are marked with that red stamp "Mrs. Tília Dulce's Legacy".

Going out, Adozinda remembers she must get some stamps for Brazil. Both papas' sisters immigrated to Minas Gerais when they became of age, marrying, and forming their new families there. The eldest was a bold, active woman who soon fit in the new country, marrying there, and sending her baby sister a boat ticket so that she might join her and start a new life there too. Brazil presented a lot of opportunities for young women who didn't have a large dowry to rest upon. Papa's brothers all immigrated to the colony of Mozambique, working for the Zambezi Tea Company.

Arriving home she tells Mama about her new experience in the library: "I felt like one of those women living in Switzerland or France, reading and all, not being gazed at, not

\footnotetext{
17 (Almeida, 1913, p.17).

18 (Almeida, 1913, p.10).
} 
afraid of being named a "literate" or a "wiseacre"19 as those boys in the street called me and my female colleagues when we were entering the faculty carrying our books."

\section{THEN, THEORETICAL ANALYSIS ENTERS}

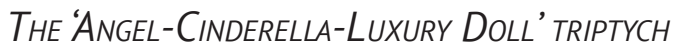

Ideologically, as Virgínia Almeida (1913) herself so sharply wrote, women's essentialized portrait was in fact a facetted one, either with angelical garments, frail and in need of guidance, as social appeasers and divine tools, used for the moral betterment of men and children, or, as productive/reproductive Cinderellas, during more earthly tasks, or yet as luxury dolls, the visible icons of their husbands social status during social events. Such figurations are typically a bourgeois construct, as the latter fold in this triptych most clearly shows. Apart from eroding individual, cultural differences among women, this ideological construct also has the effect of eroding any other inequalities such as social class or ethnicity.

The advocacy for this separatism sounds bizarre to the contemporary reader: not only were women thought of as needing to be protected from male readers, but women's presence was, on one hand, esteemed to distract serious readers - a group they were thus not included in -, and on the other esteemed to contribute to the "moral uplifting" of public space. The same reasoning was used for other public spaces, like hotels or restaurants, on the grounds, we may guess, of their commonsensical and essentialized "purity" (van Slyck, 2001; Merrett, 2010). These contradictions in representing the women's role as public space users do show up in some statements: "Of particular concern were 'library loafers', unredeemable working class men whose loitering thwarted the noble purpose of the public library." But women might then be accused of ignoring the implicit social code of conduct for such a space: British libraries recorded complaints about women giggling and talking in the semi-sacred space of the British Library, ripping plates off fashion magazines, or about young girls eating strawberries in the company of male students (Baggs, 2005) or simply for disrupting spaces conceived of as male (Hoberman, 2002). It should be noted that, on this particular respect and in the beginning of the 1950s, only one woman was to be found among more than 20 regular staff members in this library, and among a similar number of contracted workers the only females, most likely, would be the cleaning employees, the rest being attendants.

A similar form of separatism in public libraries, according to ethnicity not gender, allowing United States black readers to enter them, is also documented along with the difficulties faced (van Slyck, 2001).

By that time, and in other countries, several public libraries had separate spaces, from ladies' reading rooms, or alcoves to ladies' tables. The scarce literature on this theme describes mainly USA and UK cases (van Slyck, 1996; Hoberman, 2002; Baggs, 2005). These areas were very popular among women in the United Kingdom, considering that about $36 \%$ of the 560 local government authorities that had adopted the Public Library Act by 1914, had made such provisions (Baggs, 2005). Women's reading clubs were relatively common in

\footnotetext{
19 (Silva, 1983).
} 
the USA, and some evolved later to municipal libraries with local government support (van Slyck, 2001). And we are also aware that Lisbon's Popular Library, dating from 1912, had separated reading rooms for different publics, "a general reading room for adults and children and a room reserved for ladies" (Melo, 2010, p. 49). In 1922, the latter was eliminated according to that year's report (Biblioteca Pública Municipal do Porto [BPMP], 1944). But this and Porto's case were the only ones we could find any trace of.

We could not find documentation on the rationale supporting the decision to open this room in the library's archives, although we became aware that the idea had crossed a previous library director's mind, in the early 1930s (Brito, 1985). The next director went on a study trip to the United States in 1948. Whether the idea was inspired by North-American practices, or by the centuries-old cultural ties linking Porto and the British Isles, is a matter we may only speculate about.

No record of separatism in public or semi-public spaces for other purposes in Portugal is known to us, as was the case for other countries. In the U.K. or the U.S., there were women parlours in post-offices, public transportation waiting-rooms, banks, restaurants, etc., from the end of the 19th to mid-20th centuries (Brito, 1985). In the neighbouring Spain, segregated places might be found in beaches, still by the end of the 1980 's ${ }^{20}$. The only common local exceptions we encountered, in those decades, were those of public primary and grammar schools, and still compliance with the law for the former was sometimes not achieved, due to logistic issues (Neves \& Calado, 2001); similarly, when attending mass, women were supposed to occupy the benches in one aisle of the church and men the other, a practice observed in the countryside in the 1940-50's, and still for some years on.

The fact that Portugal was then an incipiently industrialised country may account for this situation: "women's public silence in the post-revolutionary West [French Revolution] is an imposed condition of relatively recent origin", the gendering of space being previously constructed upon different rules. And so "modern republican politics structures can be construed as part of an elaborate defence against women's power and public presence" (Landes, 1988, p. 203-204). Portugal had, for this matter, economic, cultural, historical conditions which were different from other areas in the West: women had soon, and in great numbers, left home to work for a wage; women's economic status could be high in some rural regions (Durães, 2000), confirming the theory that "the patterns, the scope and the intensity of such oppression [patriarchy] are not uniform or easily transferable across cultural-historical divisions." (Landes, 1988).

The home to women, the square to $m e n^{21}$, went the Portuguese popular saying.

Conquering multiple spaces was a women's hard battle in search of recognition as qualified users and producers of public space, no longer as mere ornamental objects. However, to remain unnoticed, might have been and still is a tactic chosen by women, as Certeau's "poacher" (1984) resorting to the tactics of resistance in fields of domination. The

\footnotetext{
$\overline{20}$ there were separate spaces with paid access for single women, single men and families both in the stretches of sand and the sea, wires dividing those areas; in the Barcelona region, this practice only ended in 1988 with the works for the Olympic Games.

${ }^{21}$ cited by Neves \& Calado (2001, p. 25).
} 
"right to be anonymous, to be left alone, not to be looked at" (Tonkiss, 2003, p. 24) may be a tactics of women in securing their right to use public space at will, through the means of an apparently negative freedom. To appropriate public space, middle-class women would also have to drop those angelical wings, cumbersome and alien to such utilitarian, rationalised places. We may sense, from some the statements of women in the consulted literature, that this was not an easy step. The ideology of an essentialized frailty and sensitiveness was shared by many women and, we may speculate, even occasionally appreciated and equated to a sign of deference from bourgeois social etiquette, according to common sense. As already claimed, women were not absent from public space in the 1950s Portugal. Working class women had already taken to the square and to the street, not out of whim or liberatory attitude, but out of the daily need for bread earning: young or old, they might be seen there, as peddlers, prostitutes, or clerks and assistants, in the streets, in semi-public places such as stores and those of public services. Women from the common classes moved more freely, out of economic necessity. They worked hard, as hard as or harder than men, and in many different occupations (Vicente, 2001). And these were the most silenced, and, most probably, the greatest pragmatic contributors to the securing of these spaces, although very likely as secondary figurants. Doors and windows began to open up to higher social class women in the second half of the 19th century.

However, space was in fact, as Lefèbvre (1991) might say, not only scenery for women's struggle but also its object. In Kerber's words (1997, p. 184) "the evidence that the woman's sphere is a social construction lies in part in the hard and constant work required to build and repair its boundaries".

The patriarchal gaze had, however, constructed a landscape through a mental selection operating on visual perception. Just as some urban figures still remain mostly invisible in present times - beggars, homeless persons, those down the social status scale, or better, those for whom no scale is available - so the physical presence of women in public space, most particularly working, lower-class women, was invisibilized. The mechanical eye of the photographic camera, however, did register them, as we can conclude from the photographs analysed for this paper. Only the sexually loaded figure of the woman was to attract the eye of the male stroller, as the product of a negative selection. Furthermore, women's new role as public library readers reinforced women's identity in a positive way, in a period when it was clearly being re-constructed, through the incorporation of new experiences in their everyday life (Alcoff, 1994).

Accordingly, we adopted the concept of gendered spaces, instead of the dual spheres binary, which oversimplifies the relations between private and public, or female and male, as a more realistic analytical tool to deal with spatial gender differences and relations (Kerber, 1997; Merrett, 2010). Nevertheless, we also stress the need not to erase other issues such as, for the case under analysis, social class, and situational issues such as history, culture or economics. 


\section{The Feminine Reading Room}

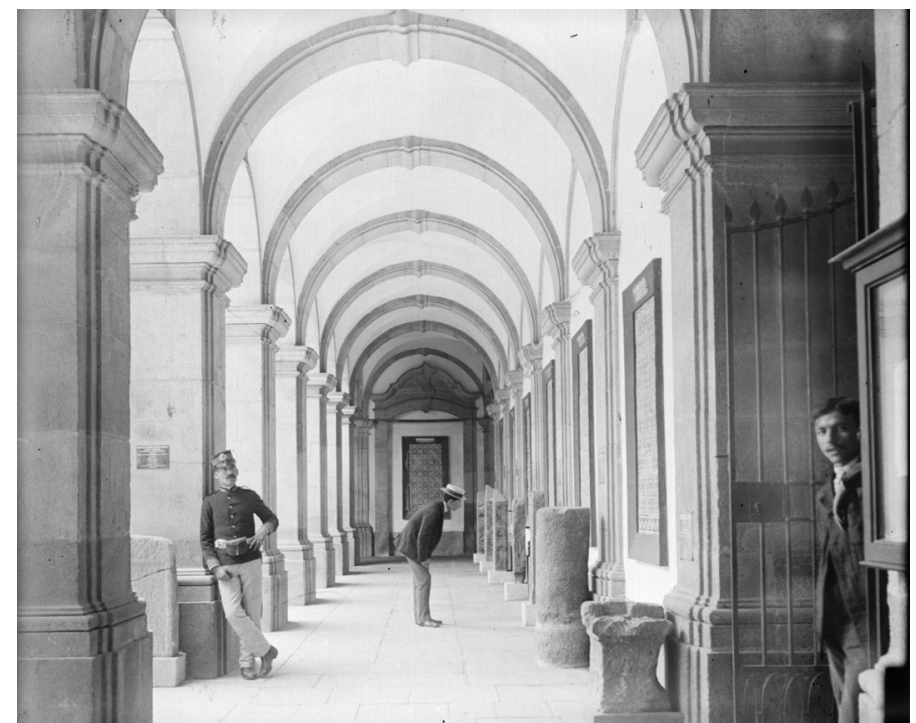

Figure 4: The cloister, Aurélio da Paz dos Reis studio, 1906, (ref. APR6718, CPF/DGARO/MC)

This library's space was the itself object of moral vigilance as to "behaviours which are contrary to morals and good manners": "creatures of different sexes come together frequently in the less frequented spots in the cloister, then indulge in practices that are anything but uplifting and have been downgraded by several persons." The lack of police surveillance led to the "scandalous scenes" to which a professor at the School of Fine Arts drew the attention of the director (BPMP, 1944) 22.

Beyond the remarks above made on the Feminine Reading Room's decoration, we should also stress the following: two photos illustrating the article on its inauguration (Inauguração..., 1945) show an empty room from different angles, and one portraits some of the persons intervening in the ceremony, most likely members of the City Council and guests. The photo reproduced above, by the same photography studio, undated, may have been taken later. We may wonder whether this is a real or staged scene of what might be a group of young girl students accompanied by a female teacher (on the far right). But, just as with those other three pictures, no caption or further information is available.

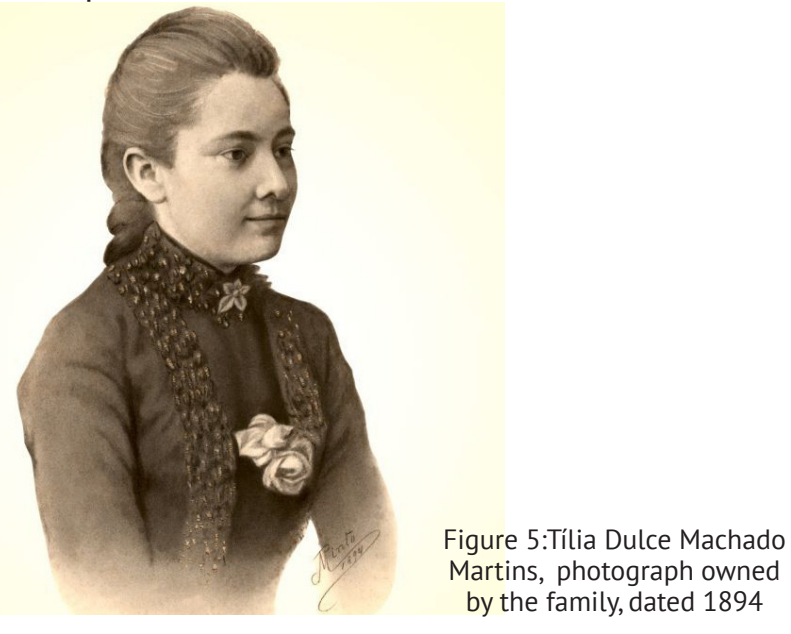

\footnotetext{
22 report dated $13^{\text {th }}$ July 1944 , in the Library's administrative archives.
} 
The topographic card catalogue produced for this Room still exists. From it and from the analysis of those books we concluded that, surprisingly, most of them were not be expected to be considered "appropriate" for a feminine readership then, as discussed further. Many of them were, by then, included in the censorship blacklist.

This legacy collection holds, predominantly, titles by renowned authors connected to the history of the French Revolution (e.g., Lamartine); by French writers (Alphonse Daudet, Baudelaire, Balzac, Molière, Verne, Hugo, but also Zola and Proudhon); by Portuguese $19^{\text {th }}$ century novel writers, many of them also liberal politicians (Herculano, Castilho, Oliveira Martins, Garrett, Camilo, Teófilo Braga, Eça); by Conan Doyle; Boccacio was also to be found; and some of its authors were certainly in the censors' blacklist then - as Marx's and Engel's Manifest or Kropotkine; there are books on parliamentary matters and hygienism, but also technical books on oenology, chemistry and physics; a few bound newspaper titles are also included, those of a humoristic genre exhibiting popular caricaturists' works, as those by Bordallo Pinheiro. Several novels by Virgínia de Castro e Almeida, by Stefan Zweig and Emilio Salgari, were later added to this Room's collection as well as approximately two hundred titles authored, prefaced or translated by Camilo Castelo Branco ${ }^{23}$. Some titles from other legacies ${ }^{24}$ were also included. These titles, as opposed to those in Tília Dulce's legacy, correspond to a selection one might anticipate for the intended readership in such a historical context. However it should be noted that such books, although polemic as they might have been, were not available on free-access but locked in bookshelves as usual in those days. We may guess that the commission appointed to select books for this room integrated the whole Tília Dulce collection, following the usual practice for legacies. Their judgement must have been exercised only over the latter additions.

The Feminine Reading Room was the object of extension works in 1947. Female visitors increased significantly between 1948 (3.3\% of in-room readers) and 1950/51 (more than 10\%). In 1952, new extension works were envisaged. Future statistics will only show aggregated data on the reading and readers for the whole institution. And the Report on 1954 activities specifically states that, after two year-long expansion works, only two special rooms remain operational in the ground-floor and none is the Feminine Reading Room. The Room was most likely closed after August 1953.

During the first weeks of existence, the readers' registry presents, predominantly, what appears to be groups of students accompanied by one teacher, which came to coincide with our interpretation of the Room's picture. Later on, female visitors are more diversified and occupations such as housewives, painters, writers, a civil engineer, an architect, seamstresses, a fishmonger, can be found, although students largely outnumber them. It became evident that there were frequent visitors, including dyads, some on a daily basis which was confirmed by our interviewee, Fernanda. The General Reading Room received then a much more socially diversified group of readers which included several manual workers. Visits totalled an average of 20 female readers per day. The feminine room opened then at 11 a.m. and closed at 5 p.m, with shorter opening hours. Some women also registered in the General Reading Room by day and even by night.

\footnotetext{
$\overline{23}$ (1825-1890), Camilo was a popular Romantic Portuguese novelist with an extense production.

24 such as titles legated by João Diogo do Carmo.
} 
No statistical registers were made on readers' gender, prior to the opening of the Feminine Reading Room, and so we cannot assess whether the offer of a separate room for women did or did not encourage their visits.

It should be noted that, from that moment on, the custom practice was that women would seat in the General Reading Room, although in a separate ally. This practice only ended during the 1960's, according to staff information.

We suppose that the children's reading room physically replaced the Feminine Reading Room, at least partially. Not only was this the information transmitted to presentday senior professionals orally, but there is a reference in the annual 1948 report to a special entrance to the children's room coinciding with that area. All we could confirm is that the children's room, created in 1948, occupied the entire south façade of the building, from 1953 or 1954 onwards $^{25}$.

\section{A HAPPY-ENDING?}

Truer than reality, the fictional narrative incorporates results of our research in order to emphasise specific situations and conditions that do not fit into a black-and-white reconstitution of such reading atmospheres: the provision of literature in the Feminine Reading Room does not appear to have been so ideologically controlled as might be expected, for reasons we could not clearly document, but may abduce. First, the fact that these books were in great part the result of a donation made by a woman from a notorious family, along with the tradition of incorporating legacies as a whole may be a partial answer to this. Second, the fact that books had to be requested from and registered with the staff, who might oppose the request and possibly report it, added another barrier of procedural control to what might appear to be free reading. Power and political relations among the library administration, the municipality and the censors, and power relations within the library itself may account for a fuller explanation.

Women were not actually absent from public space then, although their presence was frequently forced into social invisibility. Biographical research revealed another layer of invisibilisation superimposed to the use and construction of social space: the invisibilisation of women as historical agents. Was it not for Tília Dulce's marriage to a prominent man, documentation would surely be even more difficult to locate. Biographical research on two prominent women's lives was documented only at much effort, with all the traits of another form of gender invisibilisation. The biography of Virgínia de Castro e Almeida is also interesting as a reflection of the ideological oscillations that characterised some intellectuals when confronted with a fascist regime. The analysis of her biography, from the omissions to the highlights, reveals a symptomatic portrait of a woman who was notorious in the culture scene: shredded pieces assembled together and large missing pieces. Her bibliography appears to be a matter under current research. Her filmography is one of those missing pieces. A disturbing omission, as we may wonder if it might reveal a bolder facet of her personal history. She was the first producer in the Portuguese filming industry, an activity almost exclusively male, and her name sounds familiar only to a few experts in the field.

\footnotetext{
$\overline{25}$ written sources on the subject, from the administrative archives, are not clear.
} 
Although apparently contradictory in formal terms, separate spaces, which meant segregation for women in the short term, eventually contributed to processes of women's appropriation of public or semi-public space such as public libraries. If envisaged as a temporary tactical measure, the creation of separate spaces made women's presence customary in such spaces, and allowed them a previously unrecognised visibility.

The selected historical case demonstrates how this gendered appropriation of space was accompanied by conflicting tensions deriving from the power relations at stake in other areas of women's everyday life, from the labour market to the use of semi-public and public space, from family relations to the right to education. However, no documentation supporting this specific separatist policy for reading could be found.

Finally, we would like to stress that an important progress was made in the field of rights: a separate space for women, which was initially envisaged as a requirement sustained by a conservative morality, turned obsolete and evolved to a space used by both women and men. This form of space appropriation by women was to be sustained by ethical claims of a more equalitarian use of public and semi-public space, which eventually became common in other places of everyday life.

\section{BIBLIOGRAPHY}

Alcoff, L. (1994). Cultural feminism versus Post-Structuralism: the identity crisis in feminist theory. In Nicholas Dirks, Geoff Eley, and Sherry B. Ortner (Eds.), Culture power history: a reader in contemporary social theory. Princeton, N.J.: Princeton University Press.

Almeida, V. D. C. E. (1913). A mulher: história de mulher. A mulher moderna. Educação. Lisboa: Livraria Clássica.

Associação para o Ensino Bento de Jesus Caraça. (2001). O papel da Universidade Popular Portuguesa ao serviço da cultura do povo. Lisboa: CGTP. Retrieved from http://www.cgtp.pt/bjc/lido/myre. htm.

Balça, Â. (2007). Virgínia de Castro e Almeida e a colecção «Grandes Portugueses»: os livros para crianças como instrumentos doutrinários. LIBEC Line - Revista em Literacia e Bem-Estar da Criança, (2), 1-10. Retrieved from http://libecline.planetaclix.pt/n2/1GrandesPort.pdf.

Baptista, T. (Org.) (2003). Lion, Mariaud, Pallu: franceses tipicamente portugueses. Lisboa: Cinemateca Portuguesa.

Biblioteca Pública Municipal do Porto (1984). Biblioteca Pública Municipal do Porto: exposição no $150^{\circ}$ aniversário da sua fundação. Porto: BPM.

Biblioteca Pública Municipal do Porto. (1944). Relatório de actividades [archive document]. Porto.

Carvalho, R. D. (1996). História do ensino em Portugal: desde a fundação da nacionalidade até ao fim do regime de Salazar - Caetano. Lisboa: Fundação Calouste Gulbenkian.

Certeau, M. de (1984). The practice of everyday life. Berkeley: University of California Press.

Devault, M. L. (1996). Talking back to sociology: distinctive contributions of feminist methodology. Annual Review of Sociology, 22, 29-50. 
Durães, M. (2000). Qualidade de vida e sobrevivência económica da família camponesa minhota: o papel das herdeiras (sécs. XVIII-XIX). Cadernos do Noroeste, 17(1-2), 125-144.

Ferreira, M. C. F. (1935). A mulher portuguesa contemporânea: série de artigos publicados na revista Modas e Bordados: vida feminina. Lisboa: Soc. Nacional de Tipografia.

França, J. A. (1983). Sondagem nos anos 20 - cultura, sociedade, cidade. Análise Social, XIX(77-78-79), 823-844.

Fundação Instituto Politécnico do Porto; Instituto para o Desenvolvimento Tecnológico. 2000. "Realizadoras Portuguesas Notas Biográficas." In Mulheres portuguesas do séc. 20. Porto: IPP/ IDT, 2000. Retrieved http://www.mulheres-ps20.ipp.pt/Realizadoras_Txts.htm.

Guimarães, M. A. R. P. (2004). Saberes, modas \& pó-de-arroz. Entre garçonnes e fadas do Lar. Estudos sobre as mulheres na sociedade portuguesa do século XX. Coimbra: Faculdade de Letras da UC.

Hoberman, R. (2002). Women in the British Museum Reading Room during the Late-Nineteenth and Early-Twentieth Centuries: From Quasi- to Counterpublic. Feminist Studies, 28(3), 489-512.

Inauguração da “Sala de Leitura Feminina” na Biblioteca Pública Municipal. (1945). Civitas, (1), 423-430.

Kerber, L. K. (1997). Separate spheres, female worlds, woman's place: the rhetoric of women's history. In Toward an Intellectual History of Women, 159. Chapel Hill: University of North Carolina Press. 1997.

Lamas, M. (1950). As mulheres do meu país. Lisboa: Actuális.

Lefèbvre, H. (1991). The production of space. Oxford: Blackwell.

Merrett, A. J. (2010). From separate spheres to gendered spaces: the historiography of women and gender in 19th century and early 20th century America. The Proceedings of Spaces of History / Histories of Space: Emerging Approaches to the Study of the Built Environment. Berkeley: University of California.

Neves, H., \& Calado, M. (2001). O Estado Novo e as mulheres: o género como investimento ideológico e de mobilização. Lisboa: Câmara Municipal de Lisboa; Biblioteca Museu República e Resistência.

Pimentel, I. (2008). A situação das mulheres no século XX em Portugal. Caminhos da Memória. Retrieved from http://caminhosdamemoria.wordpress. com/2008/07/15/a-situacao-das-mulheres-no-seculo-xx-em-portugal-1/.

Pimentel, I. F. (2000). História das organizações femininas no Estado Novo. Lisboa: Círculo de Leitores.

Pinto, A. C. (1939). “Os Legados do Dr. José de Figueiredo e de D. Tília Dulce Machado Martins." Boletim dos Museus Nacionais de Arte Antiga, 1(1):21-25.

Pombo, A. P. (2005). Um Porto de memórias: vidas em Campanhã. Fundação para o Desenvolvimento Social do Porto.

Rosas, F. (1990). Portugal entre a paz e a guerra: estudo do impacte da I/ Guerra Mundial na economia e na sociedade portuguesa (1939-1945). Lisboa: Estampa.

Silva, M. R. T. D. (1983). Feminismo em Portugal na voz de mulheres escritoras do início do século XX. Análise Social, XIX(77-78-79), 875-907. Retrieved from http://analisesocial.ics.ul.pt/docume ntos/1223465449P2eYY6he7Ah47BN7.pdf. 
Tília Dulce Machado Cardoso. (2011). In GeneAll.net - Portugal. 2000-2011. Retrieved from http://www. geneall.net/P/.

van Slyck, A. A. (1996). The lady and the library loafer: gender and public space in Victorian America. Winterthur Portfolio, 31(4), 221-242.

Vicente, A. (2001). As mulheres portuguesas vistas por viajantes estrangeiros. Lisboa: Gótica.

Virgínia de Castro e Almeida. (2011).In Infopédia. Porto: Porto Editora. Retrieved from http://www. infopedia.pt/\$virginia-de-castro-e-almeida. 